УДК 004.9:34 (075.8)

DOI https://doi.org/10.32837/yuv.v0i4.1987

А. Борисова,

аспірант кафедри цивільного та господарського права і процесу

Міжнародного гуманітарного університету

\title{
«ІНФОРМАЦІЯ» ТА «ПРАВОВА ІНФОРМАЦІЯ» ЯК ОБ'ЄКТИ ПРАВОВІДНОСИН У СФЕРІ ІНФОРМАЦІЙНИХ КОМУНІКАЦІЙ
}

Сутність і характер суспільних відносин, що виникають між різними суб'єктами в інформаційній сфері, багато в чому зумовлюється особливостями та юридичними властивостями інформації - основного об'єкта, з приводу якого і виникають такі відносини [1]. Оскільки правовідносини, в тому числі й у сфері інформаційних комунікацій, є результатом урегулювання суспільних відносин за допомогою певної сукупності правових норм, то дослідження цих відносин одночасно означає і виокремлення їхнього основного об'єкта - інформації.

Поняття «інформація» походить від лат. informatio, що означає відомості, роз'яснення, поінформованість, ознайомлення, та відноситься до фундаментальних понять, які лежать в основі розуміння світу (час, простір, матерія, енергія і т.д.). Перші згадки про дане поняття сягають ще античної філософії [2].

Тлумачний словник C.I. Ожегова надає поняття категорії «інформація» у двох значеннях:

1) відомості про навколишній світ та процеси, які в ньому відбуваються, що сприймаються людиною чи спеціальним пристроєм;

2) відомості про стан справ або чогось іншого [3].

Сучасний словник української мови визначає категорію «інформація» як відомості про якійсь події, чиюсь діяльність тощо; повідомлення про щось [4].
За сучасних умов поняття інформації - одне з основних для науки і культури, й тому інтерес до нього залишається незмінно високим із другої половини XX століття, коли воно міцно увійшло в загальнотеоретичний ужиток. Велика кількість підходів до визначення поняття інформації, що існує в даний час, безперечно, говорить про те, що природничо-наукові галузі знання в цьому питанні досі перебувають у стані пошуку.

Поняття «інформації досліджувало багато вчених у різних галузях науки. Так, дослідженням даного поняття займались такі видатні світові вчені, як Н. Вінер, К. Шенон, В. Вернадський, Е. Тофлер, А. Хорі та інші. Вивченню загальних положень інформаційних відносин також присвячено праці зарубіжних та вітчизняних дослідників, серед яких I. Арістова, К. Бєляков, Б. Кормич, О. Кохановська, О. Ляшенко, А. Марущак, Г. Почепцов, О. Синєокий, В. Цимбалюк, М. Швець та інші. Сучасні правові відносини щодо інформації $€$ предметом регулювання нормами конституційного, кримінального, адміністративного, трудового, цивільного права, кожні з яких мають свої особливості.

Незважаючи на великий науковий доробок учених, концепція інформації недостатньо повно розглядається у сфері інформаційних комунікацій. Існує багато напрацювань у теорії інформації, в кібернетиці, інформатиці, проте в них відсутній розгляд 
даного поняття саме в контексті інформаційних комунікацій. Тому основним завданням статті $€$ аналіз та визначення понять «інформація» та «правова інформація», а також іхніх властивостей i характеристик саме в аспекті інформаційних комунікацій.

До початку промислової революції визначення суті інформації залишалось переважно прерогативою філософів. Нині даний термін розглядається в багатьох галузях знань: у системологіі, фізиці, математиці, в теорії управління, юриспруденції.

3 часом термін «інформація» як філософська категорія поступово набуває економічного, політичного, юридичного значення. Зауважимо, що термін «інформація» до недавнього часу взагалі не використовувався у сфері суспільних відносин, які регулюються нормами права. Інформація залучалась до сфери суспільних відносин як об'єкт, але лише та частина відокремленої інформації, яка має певну цінність для досягнення конкретних цілей, задоволення інтересів і потреб.

Самостійне значення поняття «інформації» тісно пов'язане 3 перспективою розвитку ринку інформаційних та телекомунікаційних технологій - побудовою «інформаційного суспільства».

Відповідно, включення в правову термінологію поняття «інформації, а також інтенсивний розвиток відповідної галузі, «інформаційного права», безпосередньо залежить від прийняття ідеології «інформаційного суспільства», яка ставить перед правовою системою конкретної держави завдання створення найбільш сприятливих $з$ точки зору законодавства умов для його формування, адже право невіддільне від загальносоціальних процесів і з необхідністю реагує на зміни, що відбуваються в реаліях сучасного життя суспільства. Важливе суспільне значення інформаційної сфери зумовлює той факт, що кожна галузь права, в межах свого предмету і методологіі, досліджує інформацію та інформаційні особливості відповідних державно-правових явищ.

В умовах глобалізації інформація проявляє себе як «цінність», що впливає на правовий статус учасників цивільно-правових відносин - фізичних осіб, юридичних осіб і держави - та економічний розвиток усього суспільства. Універсальність інформаціі, жї властивість пронизувати всі сфери суспільного життя призвели до виникнення великої кількості інформаційних об'єктів (програми, бази даних, засоби індивідуалізації, безготівкові гроші, сайти, коди доступу та ін.), з приводу яких виникають, змінюються і припиняються цивільні правовідносини. Інформаційна природа таких об’єктів впливає на їхній правовий режим, зміст і структуру, яку слід ретельно вивчити.

Вважається, що в системі суспільних відносин інформація може виступати як продукт, предмет, що має попит на ринку, вартісну оцінку і властивість товару у формі нематеріальних активів. У даному випадку інформація у формі інформаційного продукту або інформаційних послуг виступає об'єктом майнових цивільних прав, змістом яких можуть бути дві правомочності: користування i розпорядження. При цьому перше полягає в можливості вчиняти будьякі можливі і не заборонені законом або договором дії з інформацією та на iï основі, а друге - передавати інформацію в будь-якій формі будь-якій третій особі, як за плату, так і безоплатно [5].

Джерелами визначення категорії «інформація» є Конституція України, інші законодавчі й підзаконні нормативні правові акти, міжнародні договори та угоди, принципи міжнародного права, повідомлення засобів масової інформації, публічні виступи, інші джерела інформації з правових 
питань, що є передумовою багатьох юридичних фактів.

Чинне законодавство України закріплює визначення «інформації в нормативно-правових актах, и це $є$ позитивним для правового регулювання інформаційних відносин у суспільстві. Конституція України (ст. 32) закріплює положення про те, що «кожен має право вільно збирати, зберігати, використовувати й поширювати інформацію усно, письмово або в інший спосіб - на свій вибір» [6].

Саме визначення «інформації закріплено статтею 1 Закону України «Про інформацію» 1992 р., під якою законодавець розуміє «будь-які відомості та/або дані, які можуть бути збережені на матеріальних носіях або відображені в електронному вигляді» [7]. Закон визначає, що право на інформацію забезпечується шляхом:

- створення механізму реалізаціі права на інформацію;

- створення можливостей для вільного доступу до статистичних даних, архівних, бібліотечних і музейних фондів, інших інформаційних банків, баз даних, інформаційних ресурсів;

- обов'язку суб'єктів владних повноважень інформувати громадськість та засоби масової інформації про свою діяльність і прийняті рішення;

- обов'язку суб'єктів владних повноважень визначити спеціальні підрозділи або відповідальних осіб для забезпечення доступу запитувачів до інформації; здійснення державного і громадського контролю за додержанням законодавства про інформацію;

- встановлення відповідальності за порушення законодавства про інформацію [7].

О. Харенко звертає увагу на недоліки законодавчої дефініції «інформація» і вказує на те, що, по-перше, акцентується увага на тому, що обов'язковою умовою для даних та відомостей $є$ можливість їх закріплення на матеріальних носіях або відображення даних в електронній формі, тобто фіксація на електронному носії з використанням засобів обчислювальної техніки і можливістю передачі за допомогою електрозв'язку. Але якщо проаналізувати поняття «дані», стане зрозумілим, що дані передбачають їх автоматичну обробку електронно-обчислювальними пристроями, а тому $€$ очевидною їхня якість бути відображеними в електронній вигляді. По-друге, враховуючи, що під терміном «інформація» закріплюються лише «відомості та/або дані, які можуть бути збережені на матеріальних носіях або відображені в електронному вигляді», може ускладнитися його правозастосування в цивільно-правових відносинах, де інформація є нематеріальним благом і не зводиться до матеріального (фізичного) об’єкта, на якому вона зафіксована, або до відображення іiі в електронному вигляді, наприклад, у реалізації права на захист честі та гідності фізичної особи, а також ділової репутації фізичної або юридичної особи. Матеріальний носій необхідний для збереження або передачі інформації, а також інформація передається коливаннями поля, наприклад, електромагнітного [8, с. 122].

У статті 1 Закону України «Про захист економічної конкуренції» від 11.01.2001 p. закріплюється, що інформація - це відомості в будь-якій формі й вигляді та збережені на будьяких носіях (у тому числі листування, книги, помітки, ілюстрації (карти, діаграми, органіграми, малюнки, схеми тощо), фотографії, голограми, кіно-, відео-, мікрофільми, звукові записи, бази даних комп'ютерних систем або повне чи часткове відтворення їхніх елементів), пояснення осіб та будьякі інші публічно оголошені чи документовані відомості [9].

Більш змістовне поняття інформації наводилось у Законі України «Про внесення змін до Закону України «Про обмеження монополізму та недопущення недобросовісної кон- 
куренції у підприємницькій діяльності» від 1998 р.. У ст. 1 цього Закону було надано визначення інформації як засобу прояву недобросовісної (несумлінної) конкуренції в підприємницькій діяльності: «Інформація - відомості в будь-якій формі та вигляді, на будьяких носіях (у тому числі листування, книги, помітки, ілюстрації (карти, діаграми, органіграми, малюнки, схеми тощо), фотографіï, голограми, кіно-, відеофільми, мікрофільми, звукові записи, бази даних комп'ютерних систем або повне чи часткове відтворення їх елементів), пояснення осіб та будь-які інші публічно оголошені чи документовані відомості» [10].

Неабияке значення категорія «інформація» має в цивільному праві України. Саме інформація, інформаційні відносини, інформаційні права відіграють нині найсуттєвішу роль у розвитку цивілістики [11].

Правовий режим окремих видів інформації визначається спеціальними актами цивільного законодавства, які враховують іï особливість та визначають співвідношення публічних і приватних інтересів під час їі пошуку, збирання, зберігання, переробки, поширення й використання в різних сферах суспільного життя [12].

Відповідно до ст. 177 Цивільного кодексу України об'єктом цивільних прав є інформація, а також інші матеріальні й нематеріальні блага. Положення щодо оборотоздатності об’єктів цивільних прав законодавець поширює також на інформацію, яка як об'єкт цивільних прав може вільно відчужуватись або переходити від однієї особи до іншої в порядку правонаступництва чи спадкування або іншим чином, якщо вона не вилучена із цивільного обороту, не обмежена в обороті або не є невід'ємною від фізичної чи юридичної особи (ст. 178 ЦК України).

Закріплення інформаціі як окремого об'єкта цивільних прав у ст. 200 ЦК України і права на інформацію як одного 3 найважливіших особистих немайнових прав фізичної особи в низці статей Книги другої ЦК України надало поштовх для більш інтенсивного пошуку в цьому напрямі. Правовий режим інформації відрізняється від правового режиму матеріальних благ унаслідок ¥ї ідеального, нематеріального характеру, а також правового режиму особистих немайнових благ унаслідок відсутності зв'язку з особистістю, яка нею володіє. Тому інформацію відносять до нематеріальних благ, які становлять самостійний об'єкт приватноправових відносин.

O.M. Касьяненко у своєму дисертаційному дослідженні «Інформація як цивільно-правова категорія» 2009 р. підкреслює, що цивільно-правова сутність феномену інформації проявляється у вигляді відображення iii особливих властивостей у цивільних правовідносинах, до яких авторка відносить:

- оборотоздатність інформаціï, в якій знаходить відображення цивільно-правовий принцип свободи обороту;

- економічно значимий зміст інформації як спосіб безпосереднього впливу на комерційну цінність матеріального об'єкта;

- здатність інформації бути конфіденційною як стан цивільно-правового об'єкта;

- юридична і фізична невіддільність інформації від іï суб'єкта-творця (автора, володаря) як найважливіша властивість охоронюваних об'єктів інтелектуальної діяльності, нематеріальних благ і приватної таємниці (персональних даних);

- здатність інформації відображати матеріальні об’єкти цивільного характеру, не змінюючи при цьому їхніх товарних властивостей (наприклад, у правовідносинах із приводу бездокументарних цінних паперів, безготівкових грошових коштів, у ході електронних торгів, електронних розрахунків банківськими картами i т. п., які завойовують все більшу популярність 
на сучасному високотехнологічному ринку);

- необхідність фіксації інформації на будь-якому носії як умова об'єктивації, яка виступає основним критерієм правової охорони інформаційних благ;

- необхідність і можливість охорони інформації цивільно-правовими нормами [13].

О. Кохановська, виходячи з узагальненого підходу до інформації як об'єкту цивільних прав, класифікує інформацію за видом цивільних правовідносин, об'єктом яких вона виступає: на інформацію як особисте немайнове благо, тобто об'єкт немайнових відносин; інформацію як результат творчої діяльності, тобто як об'єкт виключних прав; інформацію як інформаційний продукт, ресурс, документ, тобто об’єкт, який може бути за певних умов об'єктом майнових відносин, товаром або може виступати складником таких об'єктів, як цінні папери, майно, послуги тощо [14].

О. Кулінич акцентує увагу на тому, що інформація як об'єкт цивільних прав відрізняється від матеріальних речей - об'єктів права власності своїми специфічними ознаками. На думку автора, передусім інформація $€$ ідеальним компонентом буття (нематеріальним благом). Це одна 3 найважливіших іï особливостей як об'єкту права. Саму по собі інформацію неможливо відчути, тому в більшості випадків вона опосередкує в результаті дій суб'єкта, здійснених під впливом сприйнятої ним інформації, або вона стає об’єктом права після ї фіксаціі на матеріальному носії [15].

Як зазначають дослідники, специфіка інформації, яка має своїм змістом знання і забезпечує взаємодію суб'єктів не лише інформаційних, але й інших правовідносин, та власне інформаційна сутність права [16] дозволяють вважати інформаційні права одночасно як елементом основопо- ложних та похідних прав людини всіх поколінь, так і продуктом останнього (четвертого або п’ятого) покоління еволюційного розвитку прав людини. Інформаційні права і свободи використовуються людиною у всіх сферах ii життя, на різних етапах, що підкреслює їхню виняткову значущість. Дійсно, як зазначає I. Діордіца, нині будь-які суспільні відносини проявляються через інформацію, інформаційну сферу, тому можна стверджувати, що інформаційні права і свободи $€$ в будь-якій сфері життєдіяльності суспільства [17].

Як зазначає О.В. Кохановська, до об'єктів інформаційного права належать: інформація як немайнове благо; відкрита інформація та інформація 3 обмеженим доступом (зокрема, всі види таємниць); інформаційні продукти (ресурси), документи тощо в різних сферах інформаційної діяльності; інформаційні системи (мережі, зокрема Інтернет); об’єкти права інтелектуальної власності, які не мають кваліфікуючих ознак і не визнані такими у встановленому законом порядку; відкриття; інформація, яка набуває юридичного значення в момент і за умови фіксації іï впливу на людину [18].

Інформація як об'єкт цивільного права розглядається у таких проявах: як особисте немайнове благо в комплексі благ, наведених у ст. 201 та Книзі другій ЦК України, право на яке закріплено в цивільному законодавстві; як результат інтелектуальної діяльності, тобто як об'єкт виключних прав, урегульованих у ст. 199 ЦК України; як інформаційний продукт, ресурс, документ, тобто об'єкт, який може бути інформаційним товаром і предметом будь-яких правочинів, з урахуванням особливостей та специфіки його як особливого об'єкта [19].

Слід розрізняти використання поняття «інформації» в його загальновживаному сенсі та використання як центрального поняття у правовому регулюванні конкретних суспіль- 
них відносин, безпосередньо пов'язаних 3 інформаційними процесами в суспільстві.

До початку 1970-х рр. минулого століття в юриспруденції поняття «правова інформація» практично не використовувалося. Перші дефініції правової інформації в науковий обіг вводяться у працях А. Венгерова, Ю. Кудрявцева, О. Шебанова та інших дослідників у 70-80 роках XX століття. Автори переважно підкреслюють нормативний зміст правової інформації [20], розуміють під нею сукупність відомостей про право, про процеси та явища, які пов'язані з правом [21]. Досліджуючи зміст і цілі правової інформації щодо проблеми розвитку механізмів правового регулювання, О. Шебанов підрозділив іï на два види: офіційну й неофіційну. До офіційної правової інформації він відносить зведення і дані про право чи законодавство в широкому розумінні цього поняття, тобто про всі діючи в суспільстві нормативні юридичні акти, про нормативні акти, які вже припинили дію, тощо. Як джерела цього виду інформації розглядаються Закони, Укази, різні нормативні акти місцевих органів державної влади і державного самоврядування, центральних органів та громадських організацій та ін. Як неофіційна правова інформація розглядаються всі відомості та дані про право і пов'язані 3 ним явища, що знаходяться в різноманітних матеріалах і одержуються від підприємств, установ, громадських організацій, громадян та 3 інших недержавних джерел. Це, зокрема, відомості, що містяться в юридичних монографіях, підручниках, статтях, довідниках, доповідях, оглядах та інших джерелах, які не є офіційними виданнями [22].

Відповідно до ст. 17 Закону України «Про правову інформацію» законодавець трактує правову інформацію як будь-які відомості про право, його систему, джерела, реалізацію, юридичні факти, правовідносини, право- порядок, правопорушення і боротьбу з ними та їх профілактику тощо.

Правова інформація має офіційний і документальний характер, для неї характерна системність. Існуючі наукові підходи до визначення правової інформації різноманітні в залежності від авторського розуміння даної категорії зарубіжними й вітчизняними вченими і фахівцями.

Аналіз наукових робіт дозволяє охарактеризувати наявні погляди на категорію «правова інформація». Так, О. Чапала визначає правову інформацію як будь-які відомості про право, його систему, джерела, реалізацію, юридичні факти, правовідносини, правопорядок, правопорушення і боротьбу з ними та їх профілактику тощо [23]. О. Тихомиров розрізняє поняття правової інформації в широкому та вузькому розумінні. На думку автора, правова інформація, в широкому розумінні, вбирає в себе значний масив суспільно важливої інформації i $€$ не стільки окремим видом інформації, скільки специфічною якістю тієї інформації, яка відображає процеси організації суспільного життя у сферах, охоплених правовим регулюванням. Специфіка правової інформації полягає ще й у тому, що незалежно від змісту вона завжди має певну соціальну значущість, яку ї̈ і надає така якість, як «правота» або «правність» [24].

У вузькому розумінні правова інформація має відображати основне призначення права як універсального регулятора суспільних відносин, а саме: правова інформація, яка відображає нормативні (загальнообов'язкові) або індивідуальні вимоги до поведінки (діяльності) суб'єктів, що відповідають інтересам суспільства та забезпечуються й охороняються державою [24].

Отже, термін «інформація» широко використовується в різних сферах життя, ним позначається багато явищ, які $€$ ключовими для інформаційного суспільства та важливими для 
з'ясування особливостей правового регулювання пов'язаних з ним відносин. Також поступово у сфері юридичної діяльності та правової інформатизації широко застосовується термін «правова інформація», яка також є об’єктом інформаційних правовідносин взагалі та у сфері інформаційної комунікації. Тому правове регулювання відносин у сфері інформаційних комунікацій $є$ однією 3 актуальних проблем сучасної юриспруденції, яка має осмислити природу віртуальної реальності, яка створює особливий тип буття, пов'язаний 3 розповсюдженням нових форм комунікації та інформаційних технологій.

У статті аналізуються визначення категорій «інформація» та «правова інформація» в контексті дослідження приватноправових відносин у сфері інформаційних комунікацій. Встановлено, що інформація $і$ правова інформація $\epsilon$ основними об'єктами інформаційних правовідносин взагалі та правовідносин у сфері інформаційних комунікацій. Також, незважаючи на великий науковий доробок учених, концепція інформаціі недостатньо повно розглядається у сфері інформаційних комунікацій. Існуе багато напрацювань у теоріі інформації, кібернетииі, інформатиці, проте в них відсутній розгляд даного поняття саме в контексті інформаційних комунікацій.

Доведено, щуо категорія «інформація» має неабияке значення $у$ ицвільному праві України. Саме інформація, інформаційні відносини, інформаційні права відіграють нuнi найсуттевішу роль у розвитку цзивілістики. Так, встановлено, що правовий режим окремих видів інформації визначається спеціальними актами ицивільного законодавства, які враховують ї особливість та визначають співвінношення публічних $i$ приватних інтересів під час ї пошуку, збирання, збе- рігання, переробки, поширення й використання в різних сферах суспільного життя.

Встановлено, що сліо розрізняти використання поняття «інформації» в його загальновживаному сенсі та використання як иентрального поняття у правовому регулюванні конкретних суспільних відносин, що пов'язані з інформаціиними комунікаціями. Так, у науці та національному законодавстві розрізняють поняття інформацї та правової інформаціï. Правова інформація має офіційнии $i$ документальний характер.

Інформація як об’єкт изивільного права розглядається в таких проявах: як особисте немайнове благо, право на яке закріплено в ичивільному законодавстві; як результат інтелектуальної діяльності, тобто як об'єкт виключних прав; як інформаційний продукт, тобто об'єкт, який може бути інформаційним товаром $і$ предметом будьяких правочинів.

Правова інформація має офіційний $i$ документальний характер, для неї характерна системність. Існуючі наукові підходи до визначення правової інформації різноманітні в залежності від авторського розуміння даної категорії зарубіжними $i$ вітчизняними вченими $i$ фахівиями.

Ключові слова: інформація, правова інформація, відносини у сфері інформаційних комунікацій, цивільне право, об'єкт цивільного права.

Borisova A. "Information" and "legal information" as objects of legal relations in the field of information

The article analyzes the definitions of the categories "information" and "legal information" in the context of the study of private law relations in the field of information communications. Also, despite the great scientific achievements of 
scientists, the concept of information is not fully considered in the field of information communications. There are many developments in information theory, cybernetics, computer science, but they do not consider this concept in the context of information communications.

It is proved that the category "information" is of great importance in the civil law of Ukraine. It is information, information relations, information rights that play the most important role in the development of civilization today. Thus, it is established that the legal regime of certain types of information is determined by special acts of civil law, which take into account its features and determine the ratio of public and private interests in its search, collection, storage, processing, distribution and use in various spheres of public life.

It is established that a distinction should be made between the use of the concept of "information" in its common sense and the use as a central concept in the legal regulation of specific social relations related to information communications. Thus, science and national law distinguish between the concepts of information and legal information. Legal information is official and documentary.

Information as an object of civil law is considered in the following manifestations: as a personal intangible good, the right to which is enshrined in civil law; as a result of intellectual activity, is as an object of exclusive rights; as an information product, is an object that can be an information product and the subject of any transactions.

Legal information has an official and documentary nature, it is characterized by systematicity. Existing scientific approaches to the definition of legal information are diverse depending on the author's understanding of this category by foreign and domestic scientists and specialists.

Key words: information, legal information, relations and spheres of information communications, civil law, object of civil law.

\section{Література}

1. Коваленко Л.П. Деякі питання щодо визначення інформаційного права. URL: file: / / / : / \% D0\% 97\% D0\% BO\% DO $\%$ B3\% D1\% 80\% D1\% 83\% D0\% B7\% D0\% $B A \%$ DO $B 8 \% 20 \%$ D0\% B8\% DO $\%$ B7\% 20 $\%$ DO $\mathrm{B} 8 \%$ DO\% BD\% D1\% $82 \%$ DO $\%$ B5\% D $1 \% 80 \%$ D0\% BD $00 \%$ B5\% D $1 \% 82 \%$ D 0\%BO/uy_2014_2_18.pdf

2. Джохадзе Д.В. Античная философия: проблемь историографии и теории познания. Москва, 1991. 133с.

3. Ожегов С.И. Словарь русского языка. Москва, 1990. С. 253.

4. Академічний тлумачний словник. URL: http: / / sum.in.ua/s/informacija

5. Самохвалов А.А. Информащия как объект гражданских прав. URL: штш. yurclub.ru/docs / pravo/1503/4

6. Конституиія України: Прийнята на $V$ сесії Верховної Ради України 28 червня 1996 р. Відомості Верховної Ради України. 1996. № 30. Сm. 141. URL: http://zakon2.rada.gov.ua/laws/ show / $254 \%$ D0\% BA / 96

7. Про інформачію : Закон України: від 02.10.92 р., Редакція від 01.01.2017 p. № 2657-12. URL: https: / / zakon.rada.gov. ua/laws/show/2657-12

8. Харенко O.В. Поняття «інформація» в юридичній науці та законодавстві України. Часопис Київського університету права. 2014. № 3. С. 119-124.

9. Про захист економічної конкуренції : Закон України: від 11.01.2001 p. № 2210-III. URL: https: / / zakon.rada.gov. ua/laws/show/2210-14

10. Про внесення змін до Закону Украіни «Про обмеження монополізму та недопущення недобросовісної конкуренції у підприємницькій діяльності»: Закон України від 3 березня 1998 р. № 154/98ВР. Відомості Верховної Ради України. 1998. № 34. Cm. 229.

11. Кохановська O.В. Творчість, інтелектуальна творча діяльність, інтелектуальна власність, право інтелектуальної власності: співвідношення. Сучасні проблеми приватного права : збірник 
наукових пращь, присвячених 80-й річниці з дня народження Я.М. Шевченко / відп. ред. : Н.С. Кузнєцова, Р.О. Стефанчук. Київ : ВГО «Асоціація цивілістів України»; Друкарня «Рута», 2012. С. 58, С. 131-142.

12. Заіка Ю. Скрипник В. Інформація в системі об'єктів изивільних прав. Підприємництво, господарство і право. 2017. № 1. C. 240-244.

13. Косьяненко E.M. Информация как гражданско-правовая категория : автореф. дис. ... на соискание уч. ст. к.ю.н. : 12.00 .03 «ражданское право; Предпринимательское право ; Семейное право ; Международное частное право». Екатеринбург, 2009. 26 с.

14. Кохановська О.В. Теоретичні проблеми інформащійних відносин у изивільному праві : монографія. Київ : ВПЦ «Київський ун-т», 2006. 463 с. С. 169.

15. Кулініч O.O. Інформація як об'єкт циивільних прав. Університетські наукові записки. 2005. № 3 (15). С. 126-128.

16. Данильян О.Г., Дзьобань О.П. Діалектична єдність інформаційних прав та інформаційної свободи. Вісник Національного університету «Юридична академія Украіни імені Ярослава Мудрого». 2017. № 1 (32). С. 5-15.

17. Діордіца I. Класифікація інформаціинни прав $i$ свобод людини $i$ громадянина. Підприємництво, господарство $i$ право. 2016. № 7. С. 116-122.

18. Кохановська О. Основні теорії у сфері інформаційних правовідносин: концепиія інформаційних прав як приватноправового інституту $i$ теорія інформаційного права як галузі права у сучасній правовій доктрині України. Приватне право. 2013. С. 3. URL: irbisnbuv.gov.ua

19. Кохановська О.В. Втілення та реалізація ідей розробників ЦК України щодо нормативного закріплення поняття та видів об'єктів иивільних прав. Актуальні проблеми приватного права : збірник статей до ювілею доктора юридичних наук, професора Н.С. Кузнєцової / відп. ред. : Р.А. Майданик, О.В. Кохановська. Київ : ПрАТ «Юридична практика», 2014. C. 247-271.

20. Венгеров А.Б. Категория «информацияя в понятийном аппарате юридической науки. Советское государство и право. 1977. № 10. С. 70-76.

21. Кудрявиев Ю.В. Ценность правовой информации. Правоведение. Москва, 1977. № 1. C. 45-51.

22. Шебанов А.Ф. Содержание и иели правовой информации. Правовая информация. Москва : Наука, 1974. С. 7-16.

23. Чапала О.Ю. Види інформації ma ix нормативно-правове регулювання. Форум права. 2011. № 2. С. 944-946. URL: http: / / www.nbuv.gov.ua/e-journals / FP/2011-2/11hojnpr.pdf

24. Тихомиров О.О. Правова інформаиія: теоретико-правовий аспект. Інформаційна безпека людини, суспільства, держави. 2012. № 1 (8). С. 29-35. 